\title{
Impact of Potassium-Boron Interaction on Leaf Nutrient Content and Nut Setting of Coconut
}

\author{
N. Sathi Babu ${ }^{1 *}$, A.K. Sinha ${ }^{2}$, P.S. Medda ${ }^{1}$ and A. Ghosh ${ }^{3}$ \\ ${ }^{1}$ Department of Plantation Crops and Processing, \\ ${ }^{2}$ Department of Soil Science and Agricultural Chemistry, \\ ${ }^{3}$ Department of Agricultural Statistics, Uttar Banga Krishi Viswavidyalaya, \\ West Bengal-736 165, India \\ *Corresponding author
}

\begin{tabular}{|c|c|}
\hline \multicolumn{2}{|r|}{ A B S T R A C T } \\
\hline & \multirow{6}{*}{$\begin{array}{l}\text { The experiment was conducted for two consecutive years during } 2014-15 \text { and } 2015-16 \text { at } \\
\text { the Instructional Farm of Uttar Banga Krishi Viswavidyalaya, West Bengal located at } 43 \\
\mathrm{~m} \text { above mean sea level with } 26^{\circ} 19^{\prime} 86^{\prime \prime} \mathrm{N} \text { latitude and } 89^{\circ} 23^{\prime} 53^{\prime \prime} \mathrm{E} \text { longitude. The study } \\
\text { was aimed to evaluate the effect of potassium-boron interaction on leaf nutrient content } \\
\text { and nut setting of coconut in the boron deficient soils of terai zone of West Bengal. The } \\
\text { experiment was carried out in a } 7.5 \mathrm{~m} \times 7.5 \mathrm{~m} \text {. spaced } 11 \text { years old plantation planted with } \\
\text { cv. ECT and laid out in Factorial randomized block design having } 9 \text { treatments replicated } \\
\text { four times with } 3 \text { different levels of Potassium }\left(900,1200 \text { and } 1500 \mathrm{~g} \text { of } \mathrm{K}_{2} \mathrm{O} \text { per palm) }\right. \\
\text { and Boron }(25,50 \text {, and } 100 \mathrm{~g} \text { borax } / \mathrm{palm}) \text {. Soil samples were collected from } 0 \text { to } 30 \mathrm{~cm} \\
\text { depth within a radius of } 1.5 \mathrm{~m} \text { of the trunk of each palm of the entire experimental area of } \\
\text { the plantation and the leaf samples from } 14^{\text {th }} \text { frond was taken for analysing boron and } \\
\text { potassium at } 6^{\text {th }} \text { and } 12^{\text {th }} \text { months after soil application of potassium and boron. The results } \\
\text { revealed that the leaf potassium content showed an increasing trend for the intermediate } \\
\text { levels of boron. However, higher leaf boron content recorded with higher rate of boron } \\
\text { application. The treatment receiving intermediate dose of potassium and boron registered } \\
\text { higher number of female flowers and fruit setting. }\end{array}$} \\
\hline & \\
\hline & \\
\hline Al & \\
\hline & \\
\hline & \\
\hline
\end{tabular}

\section{Introduction}

Coconut (Cocos nucifera L.) plays a significant role in the daily lives of people in over 90 countries spread along the tropical belt about 10 million people rely on coconuts as their main source of food and income. Boron is one of the micronutrients frequently reported to be in low in tropical soils; the low boron level in turn affects the nutrition and productivity of coconut palms cultivated in tropical climates as in North Bengal coconut growing soils and it plays very important role in boost up pollination and seed production. Also, it is intimately related to potassium movement in plants (Cakmak and Romheld, 1997). The studies of Sayeed (1955) revealed that of the 311 buttons produced by a normal tree annually, only 48 developed into nuts. Thus, only $15 \%$ of the buttons turns to nuts, while the remaining $85 \%$ goes waste. In the area a little information has received about mineral nutrition with respect to fruit setting in coconut palms. The most important 
observation indicate that mineral deficiencies mainly micronutrients, cause reductions due to high leaching and poor containing parent materials of soils as result number of female flowers per spadix which eventually drop off the palm a condition known as abortion of immature fruits (Holanda et al., 2007). Boron is one of most important micronutrient for yield limiting factor in coconut plantation (Santos et al., 2004). Potassium is also essential for the activation and functioning of over 60 enzymes of the plant systems. In the deficiency of potassium, the rates of the respected biochemical (enzymatic) reactions are drastically slowed down - far below the level required for the normal plant growth and development. The other notable functions of the nutrient in plants are the maintenance of cation-anion balance of in the cell, (Marschner, 2012). Report on boron and potassium on nut setting in coconut palms are scarcely found in the literature. Considering such a context, low available boron status and low to medium available $\mathrm{K}$ status of the coconut growing soils present study was to evaluate the effects of boron and potassium applied to soil by analysing the concentration of leaf nutrient contents in relation to nut setting.

\section{Materials and Methods}

The experiment was carried out during 201415 and 2015-16 at the Instructional farm of the Department of Plantation Crops and Processing, Uttar Banga Krishi Viswavidyalaya, West Bengal, India and located at $43 \mathrm{~m}$ above mean sea level at $26^{\circ} 19^{\prime} 86^{\prime \prime} \mathrm{N}$ latitude and $89^{\circ} 23^{\prime} 53^{\prime \prime} \quad \mathrm{E}$ longitude. The experimental soil was sandy loam in texture having acidic $\mathrm{pH}$ (5.45) with low in available $\mathrm{K}(87.45 \mathrm{~kg} / \mathrm{ha})$ and $\mathrm{B}(0.59$ $\mathrm{mg} / \mathrm{kg}$ ). The experiment was laid out in Factorial Randomised Block Design in a nine years old $7.5 \mathrm{~m}$ x $7.5 \mathrm{~m}$ spaced East Coast Tall coconut plantation with three different levels of potassium viz. $\mathrm{K}_{1}, \mathrm{~K}_{2}$, and $\mathrm{K}_{3}$ @ 900, 1200 and $1500 \mathrm{~g}$ of $\mathrm{K}_{2} \mathrm{O}$ and three levels of boron viz. $\mathrm{B}_{1}, \mathrm{~B}_{2}$, and $\mathrm{B}_{3} @ 25,50$, and $100 \mathrm{~g}$ borax comprising of nine treatment combinations replicated four times. All the palms were fertilized uniformly with $500 \mathrm{~g} \mathrm{~N}$ and $320 \mathrm{~g}$ of $\mathrm{P}_{2} \mathrm{O}_{5}$ per palm along with the required amount of boron and potassium as per the treatment combinations. N P K and B were applied in the form of urea $(46 \% \mathrm{~N})$, single super phosphate $\left(16 \% \mathrm{P}_{2} 0_{5}\right)$, muriate of potash $\left(60 \% \quad \mathrm{~K}_{2} \mathrm{O}\right)$ and borax $(10.5 \% \mathrm{~B})$ respectively. Half of the doses of the nutrients were applied at pre monsoon; the remaining half was applied at post monsoon at $180 \mathrm{~cm}$ away from the base of the palms (De Silva, 1968) in both the year under study. The initial soil samples $(0-30 \mathrm{~cm})$ were collected randomly before commencement of the study, thereafter sampling was done at 6 months intervals at a depth of $0-30 \mathrm{~cm}$ from $1.8 \mathrm{~m}$ away from the trunk of the palm. The leaf samples were collected from the index leaf $\left(14^{\text {th }}\right.$ frond) for analysis before application of the fertilizers and subsequently at 6 and 12 months after application for the determination of boron and potassium content of leaf (Reuter and Robinson, 1997). K content of leaf digest was determined by flame photometer as described by Muhr et al., (1965) and leaf B content was analysed by Berger and Truog (1939). The number of female flowers per spadix was counted at the time of opening of spadix and button stage of the nuts of well tagged and labelled palms. Fruit setting percentage was calculated by dividing the number of fruit sets by the total number of female flowers multiplied by 100 .

Fruit Setting percentage $(\%)=$ Initial number of fruit sets Total number offemaleflowers $\times 100$

The observations recorded in field and laboratory from different treatments were subjected to statistical analysis by adopting randomised block design as described by 
Panse and Sukhatme (1967). Treatments variations were tested for significance under different parameters were performed using Last Significant Difference (LSD) test at 5\% level of significance $(\mathrm{P}<0.05)$ by adopting $\mathrm{F}$ test (Cochran and Cox, 1975). For determination of critical difference at 5\% level of significance Fisher and Yates table was consulted. Pooled analysis over two years was also done as per method described by Gomez and Gomez (1983). Analysis of variance for each parameter was performed using ProcGlm of Statistical Analysis System (SAS) software (Version 9.3).

\section{Results and Discussion}

\section{Effect of boron and potassium application and their interactions on leaf $K$ content}

The results pertaining to the effect of application of boron at different levels on leaf $\mathrm{K}$ content are presented in Table 1 and Figure 1 and showed that there was a little variation in leaf $\mathrm{K}$ content between the two consecutive years of study. However, with increase in the level of boron application from $\mathrm{B}_{1}$ to $\mathrm{B}_{2}$, there was significant increase in leaf $\mathrm{K}$ content. Increased $\mathrm{K}$ uptake at an optimum level of soil boron has been reported by Samet et al., (2015) in pepper. With further increase in boron application rate, the leaf $\mathrm{K}$ content decreased substantially. This decrease was might be due to the toxic concentration of boron in the soil at $\mathrm{B}_{3}$ level of boron application. Mengel and Kirkby (2001) reported that excess supply of boron in growth medium reduced uptake of $\mathrm{K}$ and vice versa.

The results in relation to the effect of potassium applications at different graded levels on the leaf $\mathrm{K}$ content are also depicted in Table 1 and Figure 2 and showed that there was high consistency in leaf $\mathrm{K}$ content between the results of the two years. In any case, with increase in potassium supply, the nutrient continues to be increasingly absorbed as seen in increased leaf $\mathrm{K}$ content. Venkitaswamy et al., (2011) also reported results in similar lines.

The results revealed that the leaf $\mathrm{K}$ content was the highest in $\mathrm{B}_{1} \mathrm{~K}_{3}$ treatment followed by $\mathrm{B}_{2} \mathrm{~K}_{3}$ and $\mathrm{B}_{2} \mathrm{~K}_{2}$ treatments and it was lowest in $\mathrm{B}_{3} \mathrm{~K}_{1}$ followed by $\mathrm{B}_{1} \mathrm{~K}_{1}$ and $\mathrm{B}_{3} \mathrm{~K}_{3}$ (Table 1 and Fig. 3). Boron-potassium interactions at the applied levels and combinations caused the differences in the leaf $\mathrm{K}$ content. The results of the study suggested that, there was synergistic interaction effect between $\mathrm{K}$ and $\mathrm{B}$ in the case of $\mathrm{B}_{1} \mathrm{~K}_{3}, \mathrm{~B}_{2} \mathrm{~K}_{3}$, and $\mathrm{B}_{2} \mathrm{~K}_{2}$ treatments resulting in increased $\mathrm{K}$ uptake. The interaction between these two nutrients was antagonistic also in $\mathrm{B}_{3} \mathrm{~K}_{1}$ and $\mathrm{B}_{3} \mathrm{~K}_{3}$ combinations. Mengel and Kirkby (2001) observed that $\mathrm{B}$ and $\mathrm{K}$ interaction was negative with an excess supply of boron. All the levels of boron and potassium and their interaction effects pertaining to leaf $\mathrm{K}$ content were showed progressively decreasing trend from 6 month to 12 months after soil application of boron and potassium.

Effect of application of boron and potassium and their interactions on leaf $B$ content

The results pertaining to the effect of boron application at different rates on leaf B content are presented in Table 1 and Figure 4. A careful approval of results showed a negligible variation in leaf $B$ content between the results of the two years. With increase in the level of boron application, there was significant and proportionate increase in leaf boron content. B content in leaf increased. Similar results have been reported by Moura et al., (2013) and Nistane et al., (2011) in coconut. On the other hand, with increase in the level of potassium from $K_{1}$ to $K_{2}$, there was little increase in the leaf boron content from 23.63 to 23.78 in $2015-16$ at 6 months after application and it was statistically at par 
with each other. With further increase in potassium level, there was sharp decrease in boron content of the leaves from 23.78 to 21.05 in 2015-16 and it was statistically significant. This variation suggests negative interaction between $\mathrm{B}$ and $\mathrm{K}$ at excess levels of available $\mathrm{K}$ due possibly to cation-anion imbalance as has been reported earlier by Samet et al., (2015). The same trend was observed in 2014-15 and also in the case of pooled results for the two years (Table 1 and Fig. 5).

A perusal of data presented in Table 1 and Figure 6 showed that the leaf B content was the highest in $\mathrm{B}_{3} \mathrm{~K}_{1}$ treatment followed by $\mathrm{B}_{3} \mathrm{~K}_{3}$ and $\mathrm{B}_{3} \mathrm{~K}_{2}$ treatments. Boron-potassium interactions at the applied rates and combinations might have caused the differences in the leaf B content. This type of effect may be due to excess application of potassium caused to decrease in leaf $B$ content. The results of the study suggest that as regards to leaf $\mathrm{B}$ content, there was synergistic interaction effect between potassium and boron in certain cases and antagonistic interaction in some cases.

The results of the study are in agreement with those of present findings confirmed the findings of Ranade-Malvi (2011). Further, it appears that the individual effects of boron and potassium and also their interaction effects pertaining to the leaf boron content had a decreasing trend from 6 to 12 months after soil application of boron and potassium.

The continued decrease in leaf boron content may because of the fact that during this period (6 to 12 months), boron might have been utilized in fruit setting, boosts up pollination, seed development, formation of meristimatic tissues, synthesis of cell wall, lignifications maintenances of cell wall structure integrity nitrogen metabolism, and protein biosynthesis. A similar result was also reported by Ahmad et al., (2009).
Effect of boron and potassium application and their interaction on the number of female flower production of coconut

Data presented in Table 2 and Figure 7 clearly showed that with regard to boron application there was high consistency in the number of female flowers per spadix per palm per year between the results of the two years. In the present study with increase in the level of boron from $\mathrm{B}_{1}$ to $\mathrm{B}_{2}$, there was significant increase in the number of female flowers per spadix per palm per year. Boron at $\mathrm{B}_{1}$ level resulted in less number of female flowers could be due to low available B content of the soil. Similar results on the reduction of female flowers were reported earlier by Siqueira et al., (1997) and Holanda et al., (2007).

Boron is intimately related to all processes concerned with flowering in plants (Gupta, 2007). These flowering related functions might have contributed to the increased number of female flowers per spadix per year at a higher boron level. Increased number of female flowers per palm per year with an increase in boron content of the soils has earlier been reported by Kamalakshiamma et al., (2001) in coconut.

However, with further increase in boron level, the number of female flowers per spadix per year decreased and recorded lower value even compared to $\mathrm{B}_{1}$ level of boron also in both the year under study. As boron is a micronutrient and the range in the change from deficient to toxic concentration is extremely narrow and is often exceeded while applying boron fertilizers (Gupta, 2007). It appears that in the increase in boron level from $\mathrm{B}_{2}$ to $\mathrm{B}_{3}$, the boron levels of the soils might have reached toxic level which in turn caused a decrease female flower production`. A similar line results were reported by Lakshmipathi et al., (2015) noticed that decreased number of hermaphrodite flower production per panicle with increasing levels of boron. 
Table.1 Effect of boron and potassium application and their interaction on potassium and boron content of leaves

\begin{tabular}{|c|c|c|c|c|c|c|c|c|c|c|c|c|}
\hline \multirow{3}{*}{$\begin{array}{l}\text { Levels of } \\
\text { Boron }\end{array}$} & \multicolumn{6}{|c|}{ Leaf $K$ content (\%) } & \multicolumn{6}{|c|}{ Leaf B content (mg/kg) } \\
\hline & \multicolumn{3}{|c|}{6 months (December) } & \multicolumn{3}{|c|}{12 months (June) } & \multicolumn{3}{|c|}{6 months (December) } & \multicolumn{3}{|c|}{12 months (June) } \\
\hline & 2014-15 & 2015-16 & Pooled & 2014-15 & $2015-16$ & Pooled & 2014-15 & $2015-16$ & Pooled & 2014-15 & $2015-16$ & Pooled \\
\hline $\mathbf{B}_{1}$ & 1.72 & 1.73 & 1.73 & 1.03 & 1.03 & 1.03 & 14.09 & 14.52 & 14.30 & 8.932 & 9.034 & 8.983 \\
\hline $\mathbf{B}_{2}$ & 1.82 & 1.84 & 1.83 & 1.06 & 1.05 & 1.06 & 22.58 & 22.67 & 22.62 & 11.79 & 12.05 & 11.92 \\
\hline $\mathbf{B}_{3}$ & 1.31 & 1.31 & 1.31 & 0.86 & 0.86 & 0.86 & 30.79 & 31.27 & 31.03 & 14.77 & 14.61 & 14.69 \\
\hline $\mathrm{SE}(\mathrm{m}) \pm$ & 0.01 & 0.01 & 0.01 & 0.01 & 0.01 & 0.01 & 0.16 & 0.19 & 0.15 & 0.25 & 0.25 & 0.22 \\
\hline LSD (P=0.05) & 0.02 & 0.01 & $\mathbf{0 . 0 1}$ & 0.02 & $\mathbf{0 . 0 3}$ & 0.02 & 0.48 & 0.56 & $\mathbf{0 . 4 3}$ & 0.72 & $\mathbf{0 . 7 3}$ & 0.63 \\
\hline \multirow{2}{*}{$\begin{array}{c}\text { Levels of } \\
\text { Potassium }\end{array}$} & \multicolumn{3}{|c|}{6 months (December) } & \multicolumn{3}{|c|}{12 months (June) } & \multicolumn{3}{|c|}{6 months (December) } & \multicolumn{3}{|c|}{12 months (June) } \\
\hline & 2014-15 & 2015-16 & Pooled & 2014-15 & $2015-16$ & Pooled & 2014-15 & $2015-16$ & Pooled & 2014-15 & $2015-16$ & Pooled \\
\hline $\mathbf{K}_{1}$ & 1.12 & 1.12 & 1.12 & 0.86 & 0.85 & 0.86 & 23.22 & 23.63 & 23.42 & 12.25 & 12.34 & 12.29 \\
\hline $\mathbf{K}_{2}$ & 1.74 & 1.75 & 1.75 & 1.03 & 1.03 & 1.03 & 23.24 & 23.78 & 23.51 & 12.39 & 12.37 & 12.38 \\
\hline $\mathbf{K}_{\mathbf{3}}$ & 1.99 & 2.00 & 2.00 & 1.06 & 1.05 & 1.06 & 21.00 & 21.05 & 21.02 & 10.84 & 10.98 & 10.91 \\
\hline $\mathrm{SE}(\mathrm{m}) \pm$ & 0.01 & 0.00 & 0.01 & 0.01 & 0.01 & 0.01 & 0.16 & 0.19 & 0.15 & 0.25 & 0.25 & 0.22 \\
\hline LSD $(\mathbf{P}=\mathbf{0 . 0 5})$ & $\mathbf{0 . 0 2}$ & 0.01 & 0.01 & 0.02 & $\mathbf{0 . 0 3}$ & 0.02 & 0.48 & 0.56 & $\mathbf{0 . 4 3}$ & 0.72 & 0.73 & 0.63 \\
\hline \multirow{2}{*}{$\begin{array}{c}\text { Treatment } \\
\text { combinations }\end{array}$} & \multicolumn{3}{|c|}{6 months (December) } & \multicolumn{3}{|c|}{12 months (June) } & \multicolumn{3}{|c|}{6 months (December) } & \multicolumn{3}{|c|}{12 months (June) } \\
\hline & 2014-15 & 2015-16 & Pooled & 2014-15 & $2015-16$ & Pooled & 2014-15 & 2015-16 & Pooled & 2014-15 & $2015-16$ & Pooled \\
\hline $\mathbf{B}_{1} \mathbf{K}_{1}$ & 1.10 & 1.10 & 1.10 & 0.83 & 0.83 & 0.83 & 14.22 & 14.73 & 14.47 & 9.60 & 9.48 & 9.54 \\
\hline $\mathbf{B}_{1} \mathbf{K}_{2}$ & 1.75 & 1.75 & 1.75 & 1.04 & 1.03 & 1.03 & 15.73 & 15.98 & 15.85 & 9.98 & 10.26 & 10.12 \\
\hline $\mathbf{B}_{\mathbf{I}} \mathbf{K}_{\mathbf{3}}$ & 2.32 & 2.33 & 2.33 & 1.22 & 1.22 & 1.22 & 12.31 & 12.85 & 12.58 & 7.22 & 7.36 & 7.29 \\
\hline $\mathbf{B}_{2} \mathbf{K}_{1}$ & 1.29 & 1.30 & 1.29 & 0.99 & 0.98 & 0.98 & 22.08 & 22.32 & 22.20 & 11.39 & 11.76 & 11.58 \\
\hline $\mathbf{B}_{2} \mathbf{K}_{2}$ & 1.96 & 1.97 & 1.97 & 1.10 & 1.10 & 1.10 & 25.00 & 24.05 & 24.52 & 13.05 & 13.31 & 13.18 \\
\hline $\mathbf{B}_{2} \mathbf{K}_{3}$ & 2.21 & 2.24 & 2.23 & 1.10 & 1.08 & 1.09 & 20.67 & 20.05 & 20.36 & 10.91 & 11.06 & 10.99 \\
\hline $\mathbf{B}_{3} \mathbf{K}_{1}$ & 0.97 & 0.97 & 0.97 & 0.75 & 0.75 & 0.75 & 33.42 & 34.29 & 33.86 & 16.18 & 15.87 & 16.02 \\
\hline $\mathbf{B}_{3} \mathbf{K}_{2}$ & 1.52 & 1.53 & 1.52 & 0.96 & 0.96 & 0.96 & 28.93 & 29.28 & 29.11 & 13.72 & 13.45 & 13.58 \\
\hline $\mathbf{B}_{\mathbf{3}} \mathbf{K}_{\mathbf{3}}$ & 1.43 & 1.44 & 1.43 & 0.85 & 0.86 & 0.86 & 30.02 & 30.24 & 30.13 & 14.40 & 14.52 & 14.46 \\
\hline $\mathrm{SE}(\mathrm{m}) \pm$ & 0.01 & 0.01 & 0.01 & 0.01 & 0.02 & 0.01 & 0.28 & $\mathbf{0 . 3 3}$ & 0.25 & $\mathbf{0 . 4 3}$ & $\mathbf{0 . 4 3}$ & $\mathbf{0 . 3 7}$ \\
\hline LSD $(P=0.05)$ & 0.04 & 0.02 & 0.02 & 0.03 & 0.04 & 0.03 & 0.84 & 0.97 & 0.74 & 1.25 & 1.26 & 1.09 \\
\hline
\end{tabular}


Table.2 Effect of boron and potassium application and their interaction on the number of female flowers production and fruit setting percentage

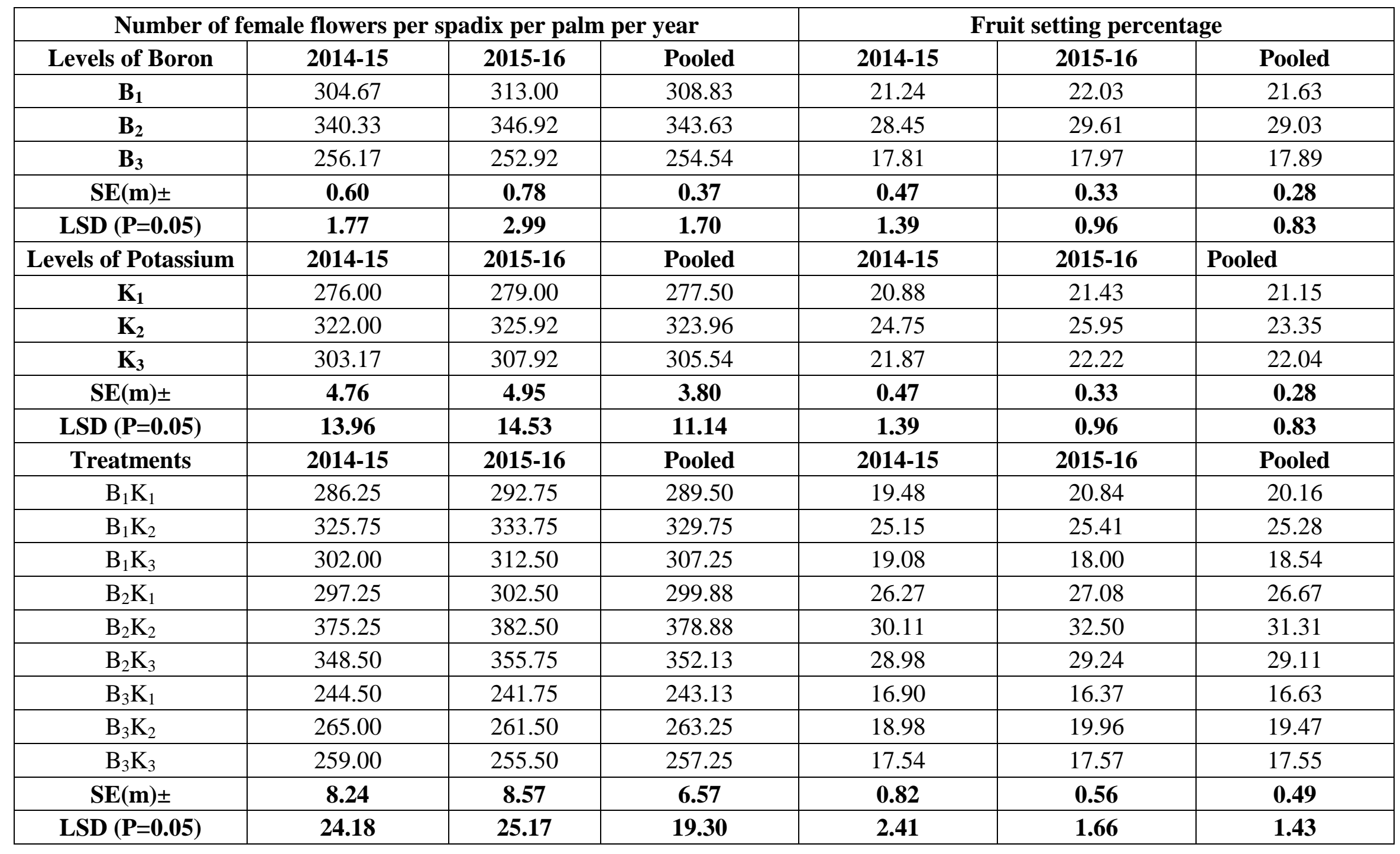


The number of nuts harvested from the mature bunches of 5 randomly selected palms were calculated for each treatment.

Notation for the treatments Levels of boron and potassium

- $\mathrm{T}_{1}: \mathrm{B}_{1} \mathrm{~K}_{1}$

$25 \mathrm{~g}$ borax/palm $+900 \mathrm{~g} \mathrm{~K}_{2} \mathrm{O} / \mathrm{palm}$

- $\mathrm{T}_{2}: \mathrm{B}_{1} \mathrm{~K}_{2}$

$25 \mathrm{~g}$ borax/palm $+1200 \mathrm{~g} \mathrm{~K}_{2} \mathrm{O} / \mathrm{palm}$

- $\mathrm{T}_{3}: \mathrm{B}_{1} \mathrm{~K}_{3}$

$25 \mathrm{~g}$ borax/palm $+1500 \mathrm{~g} \mathrm{~K}_{2} \mathrm{O} / \mathrm{palm}$

- $\mathrm{T}_{4}: \mathrm{B}_{2} \mathrm{~K}_{1}$

$50 \mathrm{~g}$ borax/palm $+900 \mathrm{~g} \mathrm{~K}_{2} \mathrm{O} / \mathrm{palm}$

- $\mathrm{T}_{5}: \mathrm{B}_{2} \mathrm{~K}_{2}$

$50 \mathrm{~g}$ borax /palm $+1200 \mathrm{~g} \mathrm{~K}_{2} \mathrm{O} /$ palm

- $\mathrm{T}_{6}: \mathrm{B}_{2} \mathrm{~K}_{3}$

$50 \mathrm{~g}$ borax/palm $+1500 \mathrm{~g} \mathrm{~K}_{2} \mathrm{O} / \mathrm{palm}$

- $\mathrm{T}_{7}: \mathrm{B}_{3} \mathrm{~K}_{1}$

$100 \mathrm{~g}$ borax/palm $+900 \mathrm{~g} \mathrm{~K}_{2} \mathrm{O} /$ palm

- $\mathrm{T}_{8}: \mathrm{B}_{3} \mathrm{~K}_{2}$

$100 \mathrm{~g}$ borax/palm + $1200 \mathrm{~g} \mathrm{~K}_{2} \mathrm{O} /$ palm

- $\underline{\underline{9}}: \underline{B} \underline{B}_{3} \underline{K_{3}}$ $100 \mathrm{~g}$ borax $/$ palm $+1500 \mathrm{~g} \mathrm{~K}{ }_{2}$ O/palm

Fig.1 Effect of soil application of B on leaf K content (\%) after 6 and 12 months of application

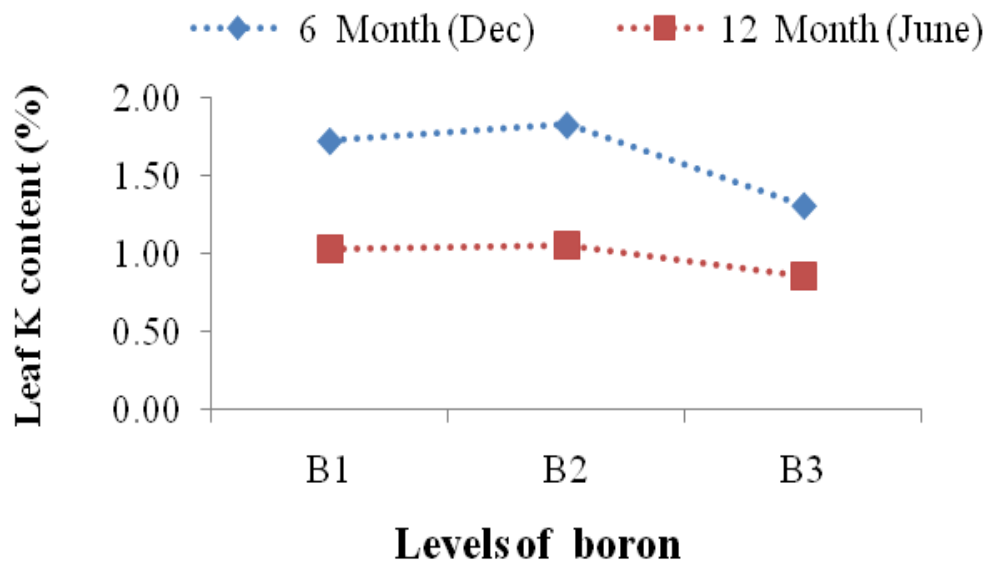

Fig.2 Effect of soil application of potassium on leaf K content (\%) after 6 and 12 months of application

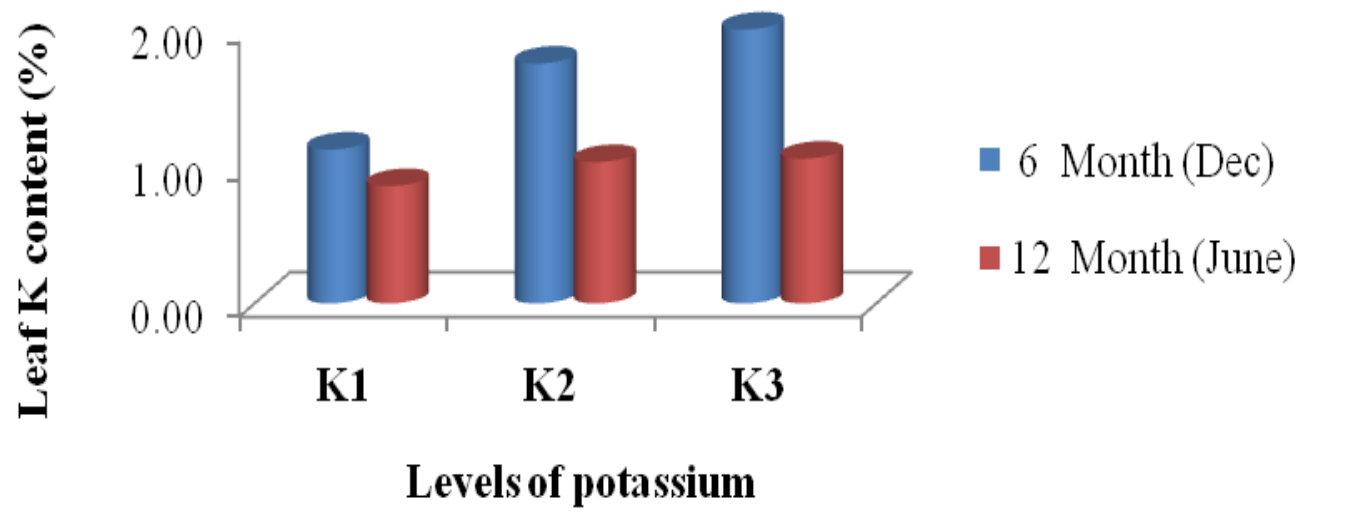


Fig.3 Interaction effect of boron and potassium on leaf potassium content (\%) after 6 and 12 months of application

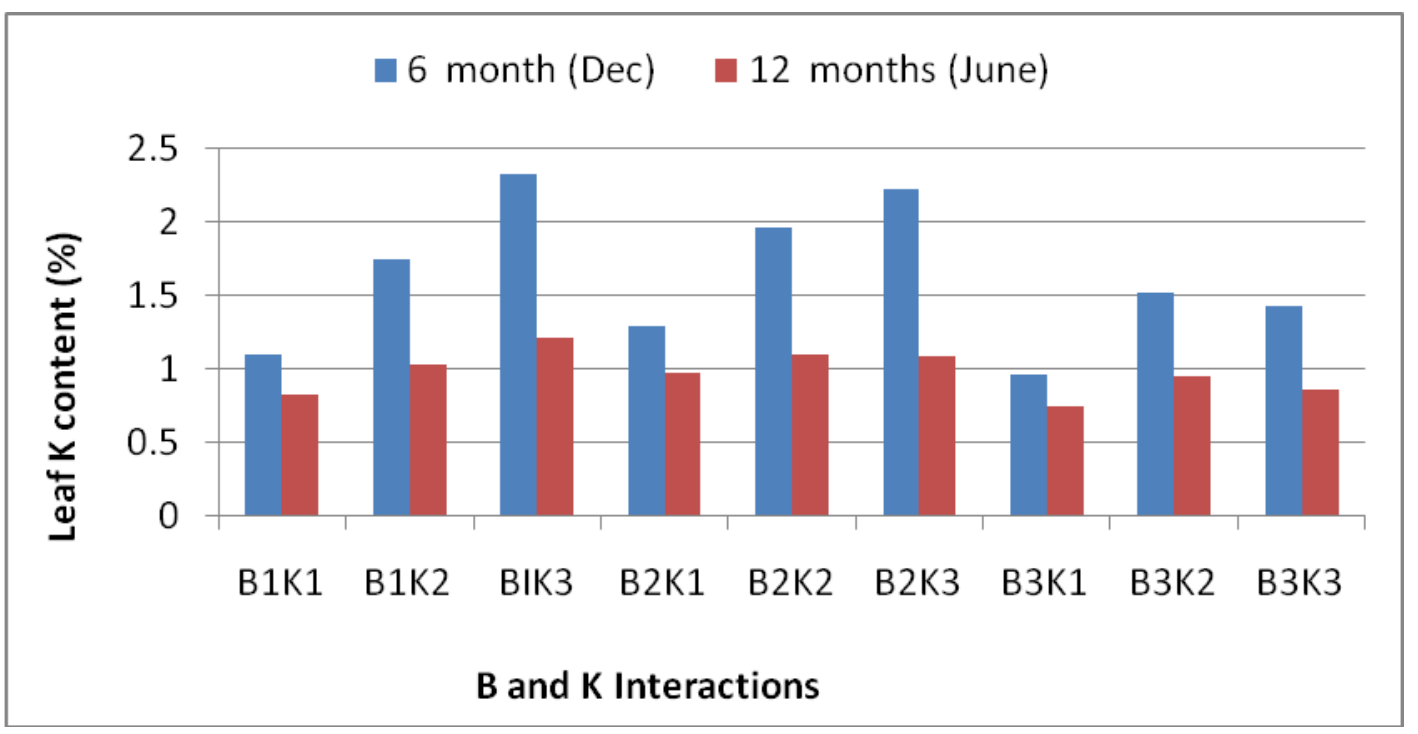

Fig.4 Effect of application of boron on leaf boron content $(\mathrm{mg} / \mathrm{kg})$ after 6 and 12 months of application

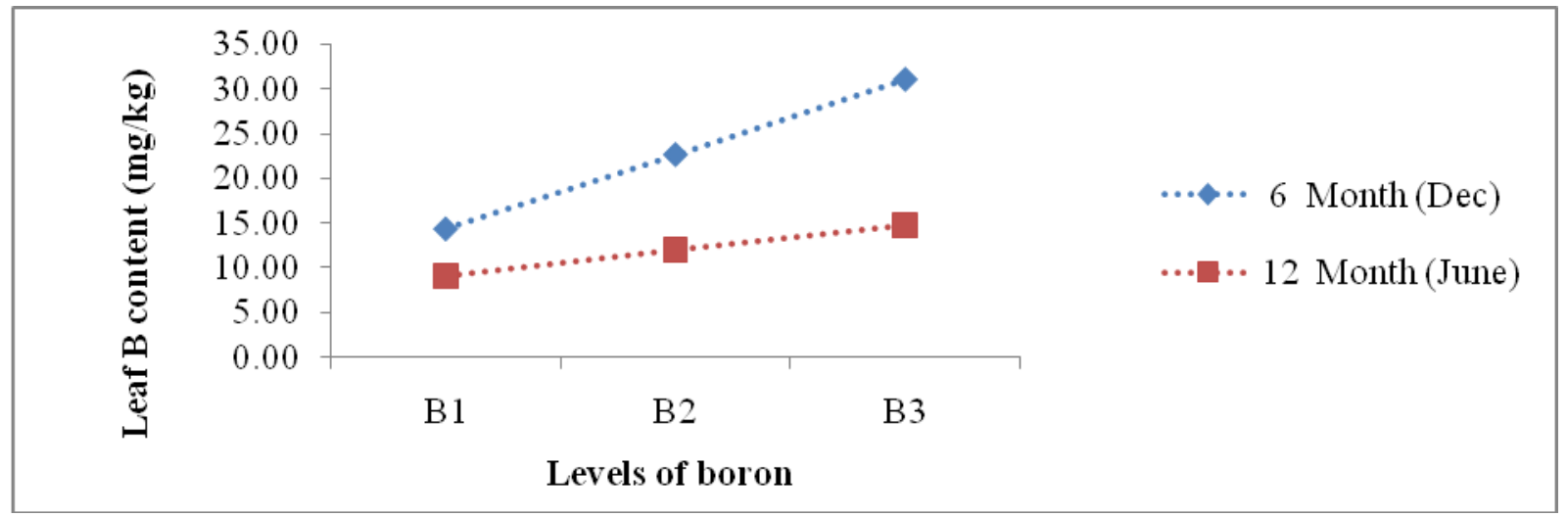

Fig.5 Effect of application of potassium on leaf boron content $(\mathrm{mg} / \mathrm{kg})$ after 6 and 12 months of application

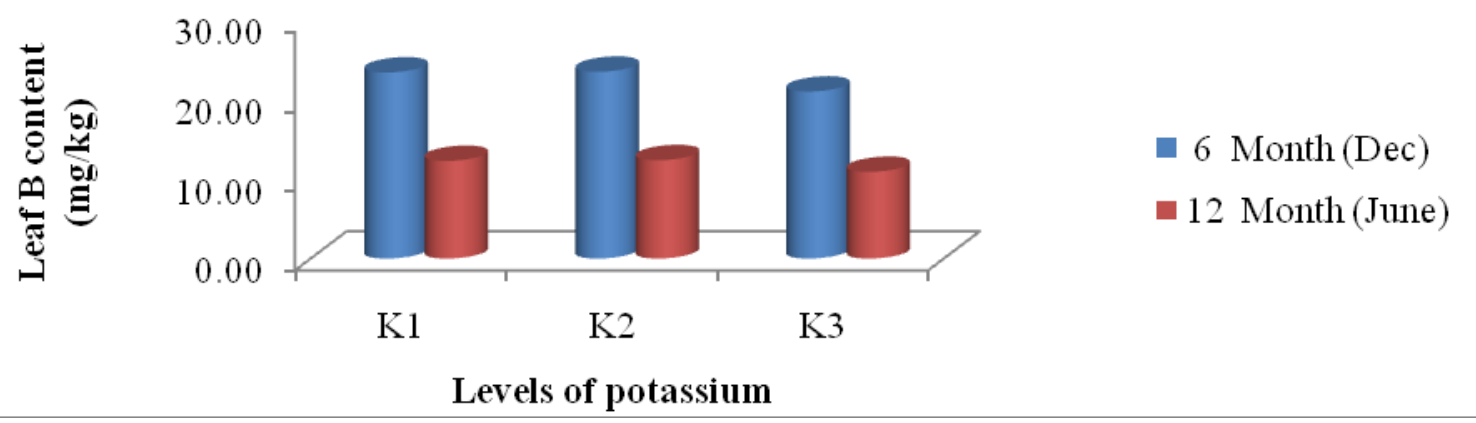


Fig.6 Interaction effect of boron and potassium on leaf boron content $(\mathrm{mg} / \mathrm{kg})$ after 6 and 12 months of application

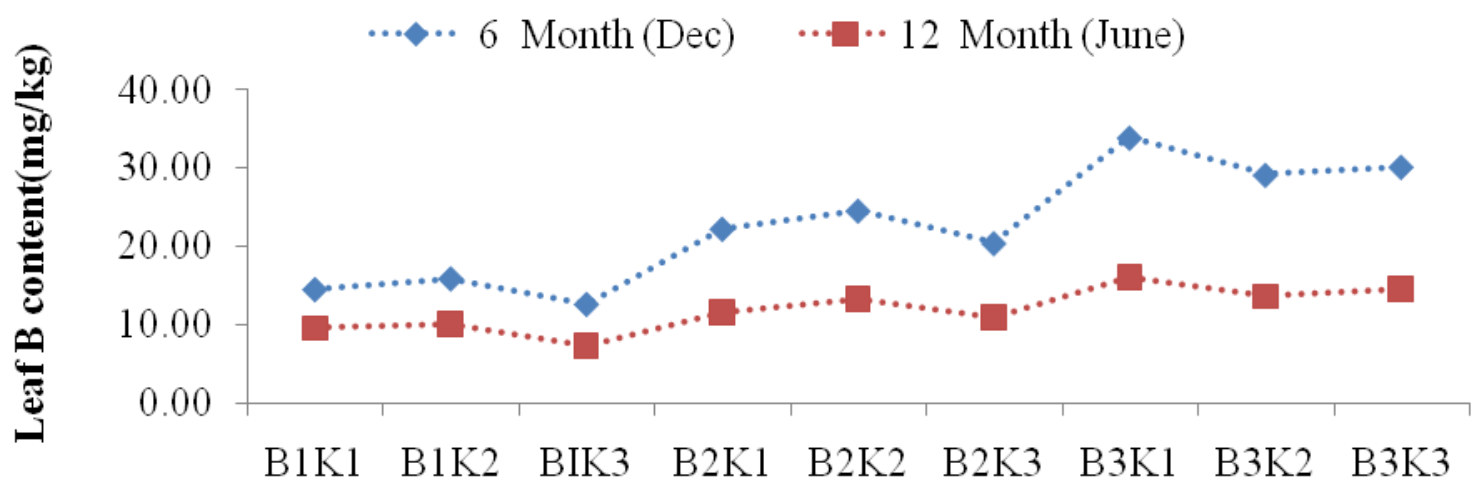

\section{$B$ and $K$ interactions}

Fig.7 Effect of boron on number of female flowers per spadix per palm per year

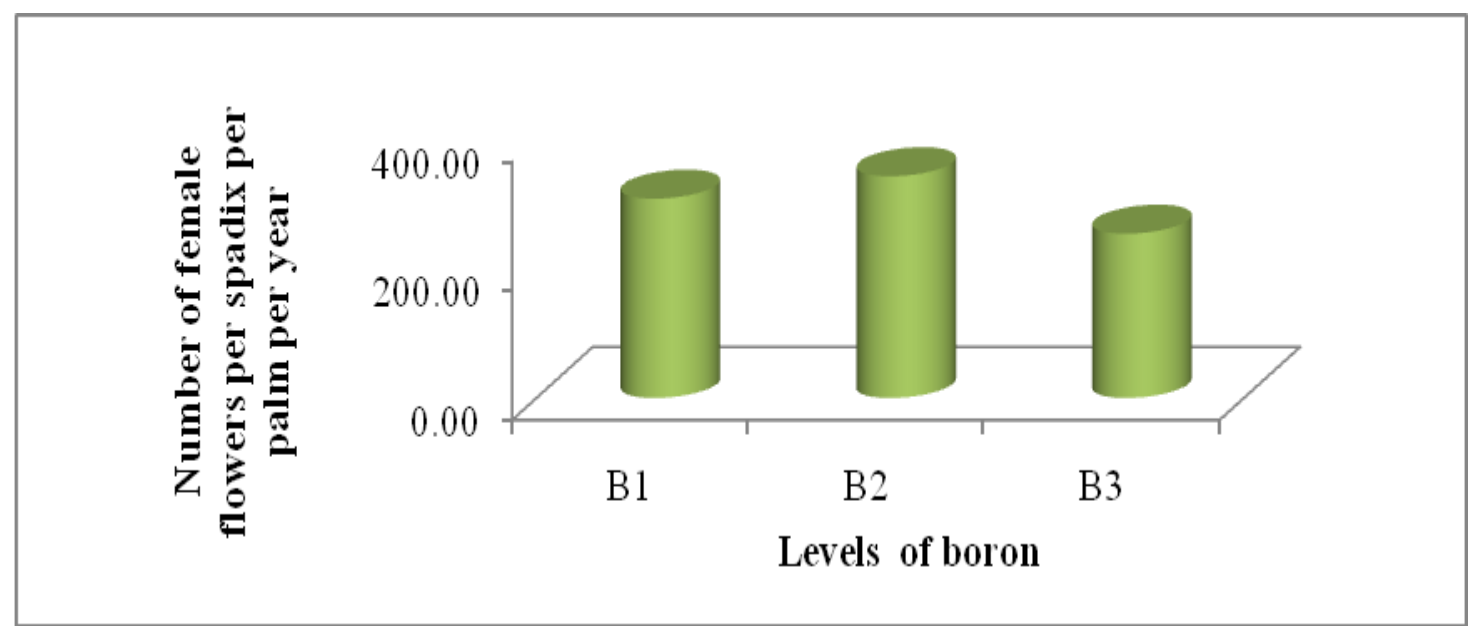

Fig.8 Effect of potassium on number of female flowers per spadix per palm per year
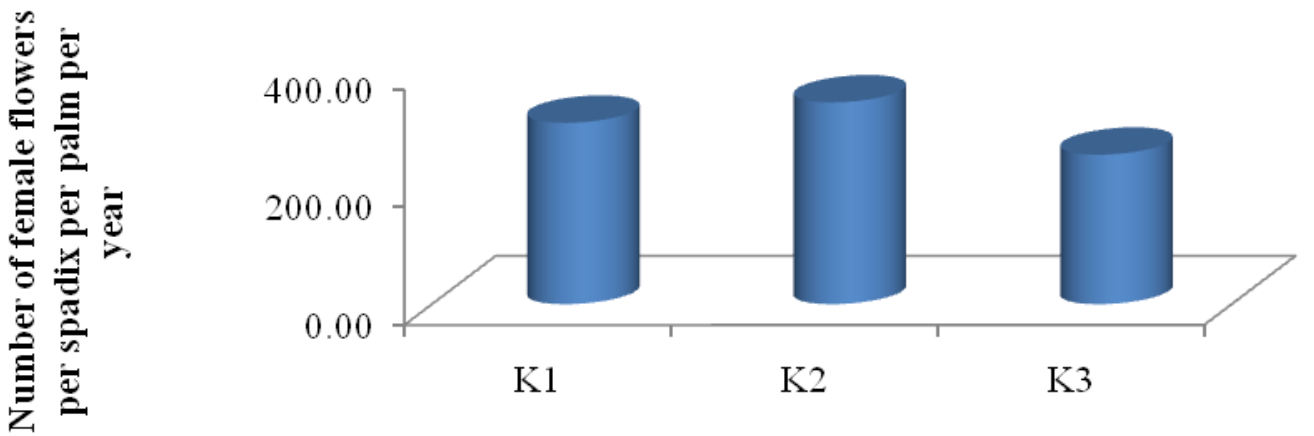

Levels of potassium 
Fig.9 Interaction effect of boron and potassium on number of female flowers per spadix per palm per year

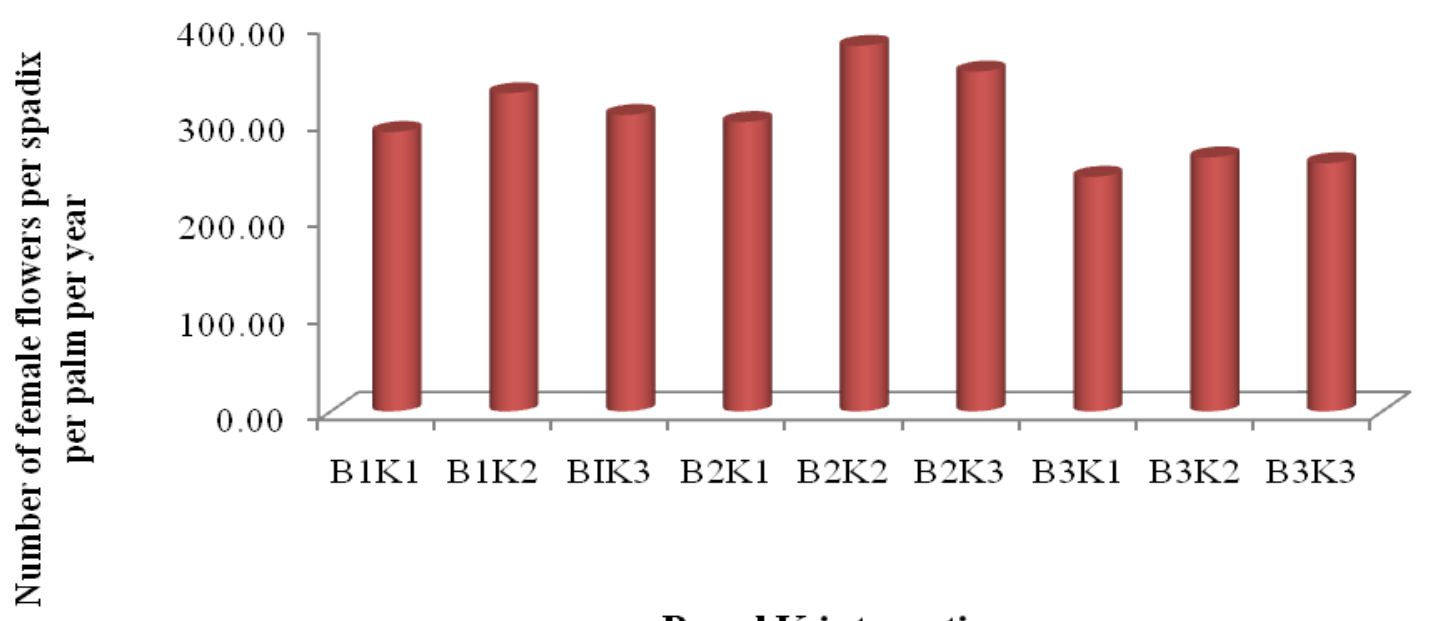

\section{$B$ and $K$ interactions}

Fig.10 Effect of boron on fruit setting percentage

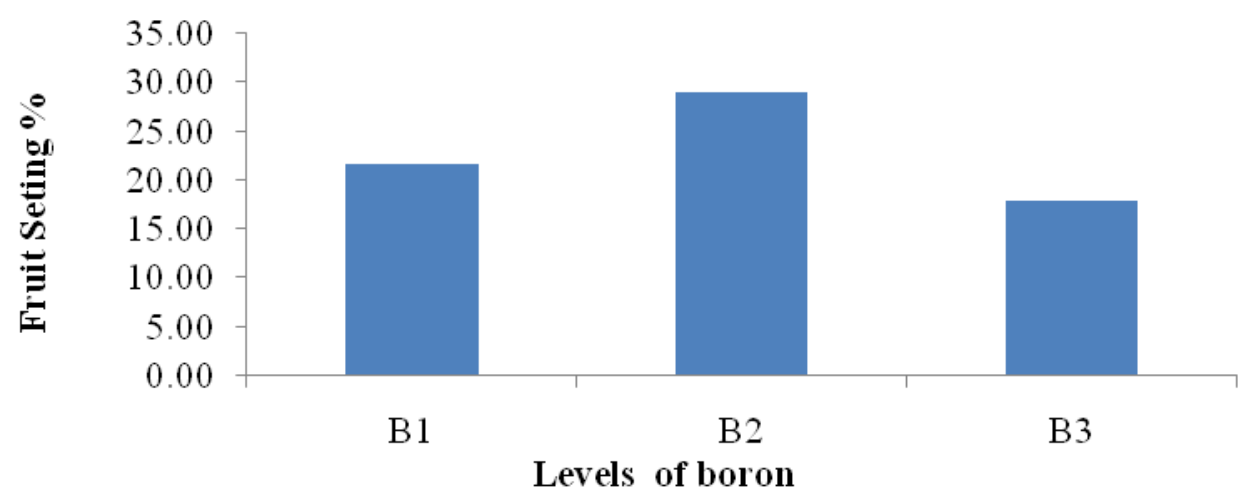

Fig.11 Effect of potassium on fruit setting percentage

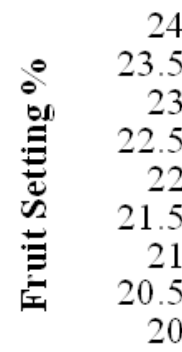

24

23

2.5

22

21

20

K2

Levels of potassium 
Fig.12 Interaction effect of application of boron and potassium on fruit setting percentage

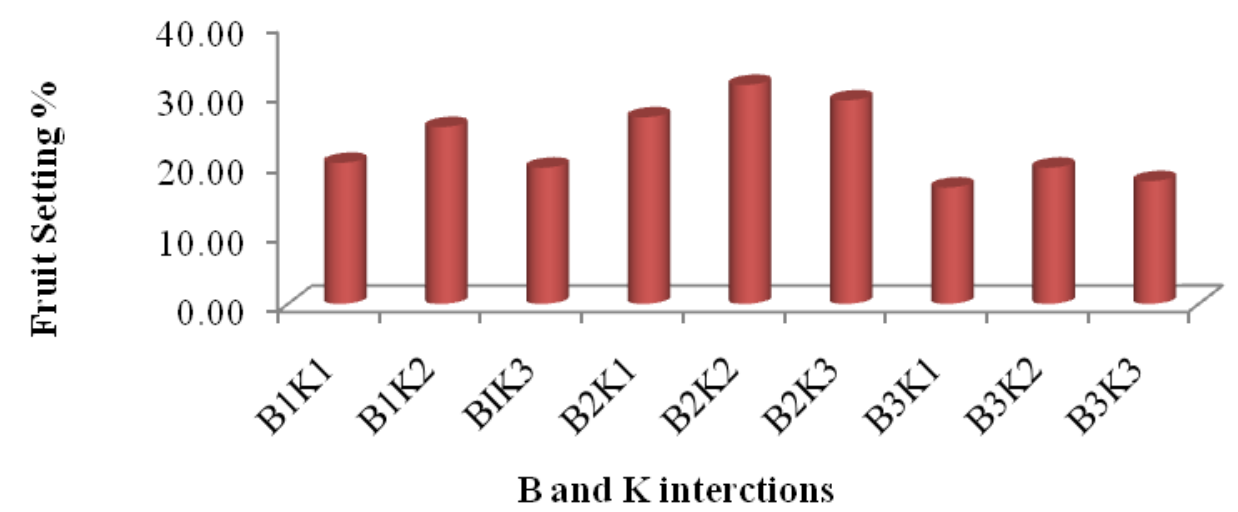

Effect of graded levels of potassium application on the number of female flowers per spadix per year was also presented in Table 2 and Figure 8. With increase in the level of potassium from $\mathrm{K}_{1}$ to $\mathrm{K}_{2}$, there was significant increased in the number of female flowers per spadix per palm per year. The increase in the number of female flowers per spadix with the increased supply of potassium must be due to the additional availability of $\mathrm{K}$ in plants. Potassium is intimately involved with the flowering and subsequent reproductive processes in plants (Mengel, 2007). Rosenquist (1980) and Venkitaswamy et al., (2011) also reported increased female flower production in coconut consequent to the application of potassium. With further increase in potassium level, the number of female flowers per spadix per year decrease significantly. Potassium at $\mathrm{K}_{3}$ level had a depressing effect on the number of female flowers per spadix per year and both the nutrients at their highest level $\left(B_{3} \& K_{3}\right)$ exhibited negative relationship and affect the availability of $\mathrm{K}$ in soil (Table 2 and Fig. 9).

The pooled data revealed that the number of female flowers per spadix per palm per year was the highest in the treatment $\mathrm{B}_{2} \mathrm{~K}_{2}$ followed by $\mathrm{B}_{2} \mathrm{~K}_{3}$ and $\mathrm{B}_{1} \mathrm{~K}_{2}$ treatments. However, at higher concentration of boron i.e.in $\mathrm{B}_{3} \mathrm{~K}_{1}, \mathrm{~B}_{3} \mathrm{~K}_{2}$ and $\mathrm{B}_{3} \mathrm{~K}_{3}$ treatments the female flower production reduced at a greater extent may be due to destabilizing the equilibrium in soil environment. Application of boron at an optimal level increases potassium permeability in the cell membrane, while an excess of the same causes negative interaction in plants (Ranade-Malvi, 2011).

Effect of boron and potassium application and their interaction on fruit setting percentage

Applications at different levels of boron and potassium had a significant effect on the fruit setting process. With increase in the level of boron from $B_{1}$ to $B_{2}$, there was significant increase in fruit setting and low fruit setting at $\mathrm{B}_{1}$ level was due to low boron content of the soils. Similar results were reported by Siqueria et al., (1997) and Holanda et al., (2007) and reported low boron content of the soils to be associated with reduction in male flowers fertility, primarily by impairing microsporogenesis and pollen tube growth having subsequent post-fertilization effects. The increased fruit setting was observed with the additional supply of boron at $\mathrm{B}_{2}$ level. However, with further increase in boron level from $\mathrm{B}_{2}$ to $\mathrm{B}_{3}$, the fruit setting decreased sharply in both the years under study as well as in pooled data also. This variation might be attributed to reaching the boron level at the point of saturation and in excess at $\mathrm{B}_{3}$ levels exert a negative effect on fruit setting. Kamalakshiamma et al., (2001) and 
Lakshmipathi et al., (2015) also noticed that the fruit setting percentage was decreased with increasing levels of boron in coconut and cashew nut, respectively which is in conformity with the present finding (Table 2 and Fig. 10).

Graded levels of potassium application also exerted a significant effect on the fruit setting process and $\mathrm{K}_{2}$ level of potassium application recorded highest number of fruit set followed by $\mathrm{K}_{3}$ level (Table 2 and Fig. 11). A similar result was obtained by Uexkull (1972) in coconut.

Results of boron-potassium interaction effects on the fruit setting process are presented in Table 2 and Figure 12 showed that the fruit setting per cent was the highest in $\mathrm{B}_{2} \mathrm{~K}_{2}$ treatment followed by $\mathrm{B}_{2} \mathrm{~K}_{3}$ and $\mathrm{B}_{2} \mathrm{~K}_{1}$ treatments. Boron-potassium interactions at the applied must have caused the differences in the fruit setting per cent. In the present study, there was synergistic interaction effect between potassium and boron in the case of $\mathrm{B}_{2} \mathrm{~K}_{2}, \mathrm{~B}_{2} \mathrm{~K}_{3}$, and $\mathrm{B}_{2} \mathrm{~K}_{1}$ treatments. Earlier, Schon et al., (1990) and Ranade-Malvi (2011) noticed that boron at an optimum level increased potassium permeability in the cell membrane, though however, an excess of the nutrient causes toxicity in plants.

\section{Acknowledgement}

At first, with a sense of deepest gratitude I do express immense indebtedness to Dr. P.S. Medda, Associate professor and Head, Chairman of my Advisory Committee, Department of Plantation Crops and Processing, Uttar Banga Krishi Viswavidyalaya, Dr. P. Mukhopadhyay, Professor, and Dr. Abhas Kumar Sinha, Associate Professor, Department of Soil Science and Agricultural Chemistry, UBKV for under taking this research work on such an important need-based subject and giving me the opportunity to carry out this experiment. Dr. A. Ghosh, Assistant Professor, Department of Agricultural statistics for designing the programme, analyzing the data and his valuable advice. I also wish to record of my profound sense of indebtedness to the members of my Advisory Committee namely, Dr. H. Bhattacharjee, Associate Professor, Department of Plantation Crops and Processing, Dr. S. Maitra, Associate professor, Department of Floriculture, Medicinal and Aromatics Crops, Faculty of Horticulture, Uttar Banga Krishi Viswavidyalaya for their learned guidance and valuable suggestions on different aspects during the tenure of this experiment period.

I would like to acknowledge to the Acharya. N. G. Ranga Agricultural University (ANGRAU) higher authorities and all the teaching staff members for their help and co - operation towards pursing my higher studies.

I convey my hearty thanks to Dr. D.K. Sarkar, Professor, Dept. of Soil Science and Agricultural Chemistry for their extending valuable help time to time.

\section{References}

Ahmad, W., Niaz, A., Kanwal, S.R. and Rasheed, M.K. (2009). Role of boron in plant growth: A review. Journal of Agricultural Research. 47: 329 -338.

Berger, K. C. and Truog, E. (1939). Boron determination in soils and plants. Ind. Eng. Chem. 11: 540-545.

Cakmak, I. and Romheld, V. (1997). Boron deficiency-induced impairments of cellular functions in plants. Plant and Soil. 193: 7183.

De Silva, M.A.T. (1968). Recommended methods of fertilizer application for coconut palms. Ceylon Coconut Planters. 3:108-111.

Gupta, U.C. (2007). Boron. In: Handbook of Plant Nutrition. Edited. by Allen V Barker and David J Pilbeam. CRC press, Taylor and Francis Group, Boca Raton. pp: 242-277.

Holanda, D.J.S., Folegatti, M.V., Gheyi, H.R., Pereira, W.E. and Cavalcante, L. F. (2007). Quality of green fruits of "anão verde" coconut in relation to doses of nitrogen and potassium via fertigation. Revista Brasileira de Engenharia Agrícolae Ambiental. 11: 453-458. 
Kamalakshiamma, P.G., Prema, D. and Shanava, M. (2001). Boron deficiency in coconut (Cocos nucifera L.). Technical bulletin No.40. CPCRI, Kasaragod.

Lakshmipathi, D., Dinakara, A. J., Kalaivanan, D., Mohanan, G. S. and Meena, R. K. (2015). Effect of foliar application of micronutrients on reproductive growth of cashew (Anacardium occidentale L.) Under South West Coast Region of Karnataka, India. Trends in Biosciences. 8 (2): 447449.

Marschner, H. (2012). In: Mineral Nutrition of Higher Plants. $3^{\text {rd }}$ edition. Academic Press, London. pp: 178-189.

Mengel, K and Kirkby, E.A. (2001). Principles of Plant Nutrition. $5^{\text {th }}$ edition. Dordrecth: Kluwer Academic Publishers. pp: 849.

Mengel, K. (2007). Potassium. In handbook of Plant Nutrition. Ed. by Allen V Barker and David J Pilbeam. CRC Press, Taylor and Francis Group, Boca Raton. pp: 91-120.

Moura, J.Z., Prado, R.M., Benvindo, R.N. and Chaves, A.L. (2013). Applying boron to coconut palm plants: effects on the soil, on the plant nutritional status and on productivity boron to coconut palm trees. Journal of Soil Science and Plant Nutrition, 13 (1): 79-85.

Muhr, G.R., Datta, N.P., Sankarasubramoney, H., Leley, V.K. and Dunabha, R.L. (1965). Soil testing in India. Second edition, USAIDMission to India, New Delhi.

Nistane, N.G., Padhiar, B.V., Bhalerao, P.P., and Bhalerao, R.R. (2011). Influence of micronutrients on flowering, yield, and quality and leaf nutrient status of coconut cv. HYBRID DXT. Asian Journal of Horticulture. 6 (1): 89-91.

Ranade-Malvi, U. (2011). Interaction of micronutrients with major nutrients with special reference to potassium. Karnataka
Journal of Agricultural science. 24 (1): 106-109.

Reuter, D. J. and Robinson, J.B. (1997). Plant Analysis: An Interpretation manual $\left(2^{\text {nd }}\right.$ edition). CSIRO Publishing

Rosenquist, K.A. (1980). A coconut fertilizer trail on the podsolic soils of North Sumatra. Oleagineux. 35 (5): 241-246.

Samet, H., Cikili, Y. and Dursun, S. (2015). The role of potassium in alleviating boron toxicity and combined effects on nutrient concentrates in pepper (Capsicum annuum L.). Bulgarian Journal of Agricultural Sciences. 21 (1): 64-70.

Santos, A.L., Monnerat, P.H. and Alves, E.A.B. (2004). Leaf boron content due to the application of borax in leaf axil of green dwarf coconut in the North Fluminense. Agricultural Research Sustainable Development. 26: 330-334.

Sayeed, P. M. (1955). Some observations on the shedding of buttons in the coconut. The Indian Coconut Journal, 8 (2): 49-57.

Schon, M.K., Novacky, A. and Belvins, D.G. (1990). Boron induces hyper polarization of sunflower root cell membranes and increases membrane permeability to $\mathrm{K}+$. Plant Physiology. 93: 566- 571.

Siqueira, E.R., Ribeiro, F.L. and Aragão, W.M. (1997). Genetic improvement of the coconut palm. In: Ferreira, JMS; Warwick, DRN; Siqueira, LAA coconut culture in Brazil. (Ed.). Aracaju. pp: 73-98.

Uexkull, H. R. (1972). Response of coconuts to (potassium) chloride in the Philippines. Oléagineux. 2: 13-19.

Venkitaswamy, R., Hameed Khan, H. and Palaniswami, C. (2011). Effect of graded levels of NPK on the reproductive characters and yield of hybrid coconut (COD X WCT). Tropical Agriculture. 86:13-20.

\section{How to cite this article:}

Sathi Babu, N., A.K. Sinha, P.S. Medda and Ghosh, A. 2017. Impact of Potassium-Boron Interaction on Leaf Nutrient Content and Nut Setting of Coconut. Int.J.Curr.Microbiol.App.Sci. 6(12): 4025-4037. doi: https://doi.org/10.20546/ijcmas.2017.612.463 